\title{
Migração makonde, produção de esculturas e mercado de arte no Tanganyika: a questão do estilo Shetani (1950-60)'
}

\section{Lia Dias Laranjeira ${ }^{2}$}

RESUMO: $\bigcirc$ presente artigo incide sobre parte da minha pesquisa de doutorado que teve como foco a produção de arte makonde em diálogo com a história política de Moçambique entre 1950 e 1974. A investigação de caráter interdisciplinar envolveu fontes de naturezas diversas, como a documentação produzida no período colonial, assim como uma bibliografia acessada em diferentes acervos de Lisboa e na Biblioteca do Museu Etnológico de Berlim, além de relatos orais coletados em Moçambique entre 2012 e 2014 . Essas fontes orais foram produzidas, especialmente, em entrevistas e conversas com escultores, os quais denominam suas respectivas peças como arte makonde. $\bigcirc$ presente texto discute o contexto de produção de um estilo de escultura específico conhecido como shetani, que foi criado no território vizinho do Tanganyika (atual Tanzânia), no final da década de 1950, por Samaki Likonkoa, artista makonde de Moçambique. Analiso aqui a referida produção no âmbito da vivência migratória internacional dos makonde de Moçambique para o Tanganyika, motivada pela busca por melhores condições de trabalho e de vida. $\bigcirc$ caso da produção desse tipo de escultura ilustra, aqui, a circulação de pessoas, objetos e conhecimento entre o sul e o norte do rio Rovuma no contexto colonial português das décadas de 1950 e 1960.

PALAVRAS-CHAVE: Arte makonde. Shetani. Mercado de arte. Moçambique colonial. Tanganyika.

ABSTRACT: This article focuses on part of my PhD research that focused on makonde art production in dialogue with the political history of Mozambique between 1950 and 1974. The research of a interdisciplinary nature involved diverse sources such as the documentation produced in the colonial period as well as a bibliography accessed in different collections of Lisbon and in the Library of the Ethnological Museum of Berlin, besides oral reports collected in Mozambique between 2012 and 2014. These oral sources were produced, especially, in interviews and conversations with sculptors, who call their respective pieces as makonde art. This paper discusses the context of production of a specific sculpture style known as shetani, which was created in the neighboring Tanganyika (now Tanzania), in the late 1950s, by Samaki Likonkoa, artist makonde of Mozambique. I analyze this production in the context of the international migratory experience
1. Este artigo integra pesquisa de doutorado realizada no Programa de Pós Graduação em História Social da USP, sob orientação da Profa. Dra. Cristina Cortez Wissenbach, e com apoio da FAPESP. Uma versão deste trabalho foi apresentada no IV Encontro Internacional de Estudos Africanos da UFF, no Museu Histórico Nacional (Rio de Janeiro), entre 25 e 28 de outubro de 2016.

2. Bacharela em Ciências Sociais com habilitação em Antropologia (UFBA), Mestra em Estudos Étnicos e Africanos (UFBA), Doutora em História Social (USP) e Professora da Unilab. E-mail: <lialaranjeira@ gmail.com>. 
3. Ver Laranjeira (2016).

4. Após a Primeira Guerra Mundial, com a ocupação inglesa na antiga África Oriental Alemã (atuais Tanzânia, Burundi e Ruanda), a Tanzânia foi renomeada como Tanganyika. Após a independência do país, em 1961, e a partir da união com o estado do Zanzibar, em 1964, o Tanganyika passou a se designar como Tanzânia. Neste texto, utilizo a denominação Tanganyika para me referir ao país no período anterior a 1964 .

5. Kangai; Mupondi (2013), Kasfir (1992), Kingdon (2002).

6. De acordo com o censo de 2007, a província de Cabo Delgado, ao norte de Moçambique, possui o número aproximado de 1.634.162 habitantes. Portanto, $20 \%$ dessa população, aproximadamente $327 \mathrm{mil}$ pessoas, tem o shi-makonde como língua materna. As outras principais línguas maternas, utilizadas na comunicação diária na província de Cabo Delgado, são o emakhuwa (67.1\%), o kimwani (6\%), o português (3.4\%) e o kiswabili (1.2\%). Fonte: <www.ine.gov.mz/ estatisticas/estatisticas-territoriais-distritais/cabo-delgado>. Acesso em: 20 jun. 2017.

7. Weule (2000, p. 83).

8. Além de Weule (1906), os viajantes David Livingstone (1866-1868), Chauncy Maples (1882), Joseph Thompson (1882) e O'Neill (1885), dentre outros, utilizam a mesma denominação ou suas variantes. of the makonde from Mozambique to Tanganyika, motivated by the search for better conditions of work and life. The case of the production of this type of sculpture illustrates here the circulation of people, objects and knowledge between the south and the north of the Rovuma river in the Portuguese colonial context of the 1950s and 1960s.

KEYWORDS: Makonde art. Shetani. Art market. Colonial Mozambique. Tanganyika.

Os makonde entre o sul e o norte do Rio Rovuma

Em pesquisa mais ampla ${ }^{3}$ na qual o presente artigo se insere destacouse a produção de um tipo de escultura específico conhecido como shetani, que segundo fontes escritas e orais, foi criada no Tanganyika ${ }^{4}$, então colônia da Inglaterra, por Samaki Likonkoa, artista makonde de Moçambique. ${ }^{5}$ A escultura shetani apresenta-se aqui como um exemplo paradigmático de uma produção escultórica que marca a transformação tanto dos tipos de peças, normalmente esculpidas em Moçambique, quanto a relação dos escultores com os comerciantes dessa arte. Proponho analisar aqui o contexto da criação desse tipo de escultura no Tanganyika relacionando-o com uma das questões centrais da história dos makonde de Moçambique: a migração em massa desse grupo para o norte do rio Rovuma, entre as décadas de 1950 e 1960, motivada pela violência do regime colonial português. Delimitando a fronteira política entre Moçambique e Tanzânia, o rio Rovuma cumpre um papel fundamental de interação entre os makonde que historicamente habitam os dois territórios.

A criação e a difusão da escultura shetani são decorrentes de uma rede de comunicação e circulação da população makonde em diferentes espaços que conectam o norte de Moçambique, com destaque para o Planalto de Mueda na Província de Cabo Delgado ${ }^{\circ}$, aos centros urbanos do Tanganyika, em especial a cidade de Dar es Salaam, centro comercial e administrativo do país e capital da Tanzânia até 1973. Assim, é importante se considerar também a dinâmica social e a circulação dos saberes que envolvem a cultura material nesses territórios.

geógrafo e etnólogo alemão Karl Weule, nos relatos sobre sua viagem nas proximidades do Rovuma, realizada em 1906, descreveu a semelhança entre os principais planaltos habitados pelos makonde em Moçambique e na Tanzânia. Localizados em posição paralela e divididos pelo rio Rovuma, o Planalto de Mueda (Moçambique) e o Planalto de Newala (Tanzânia) teriam a mesma sequência de sedimentações e de erosões "repetidas durante longos períodos geológicos"7. À época, o Planalto de Mueda era conhecido como planalto dos Mawia, denominação recorrente na literatura de viagem, ${ }^{8}$ nos estudos etnológicos e nos mapas coloniais do final do século XIX e início do XX, usada ainda hoje por parte da população do norte do Rovuma para se referir aos makonde do sul. 

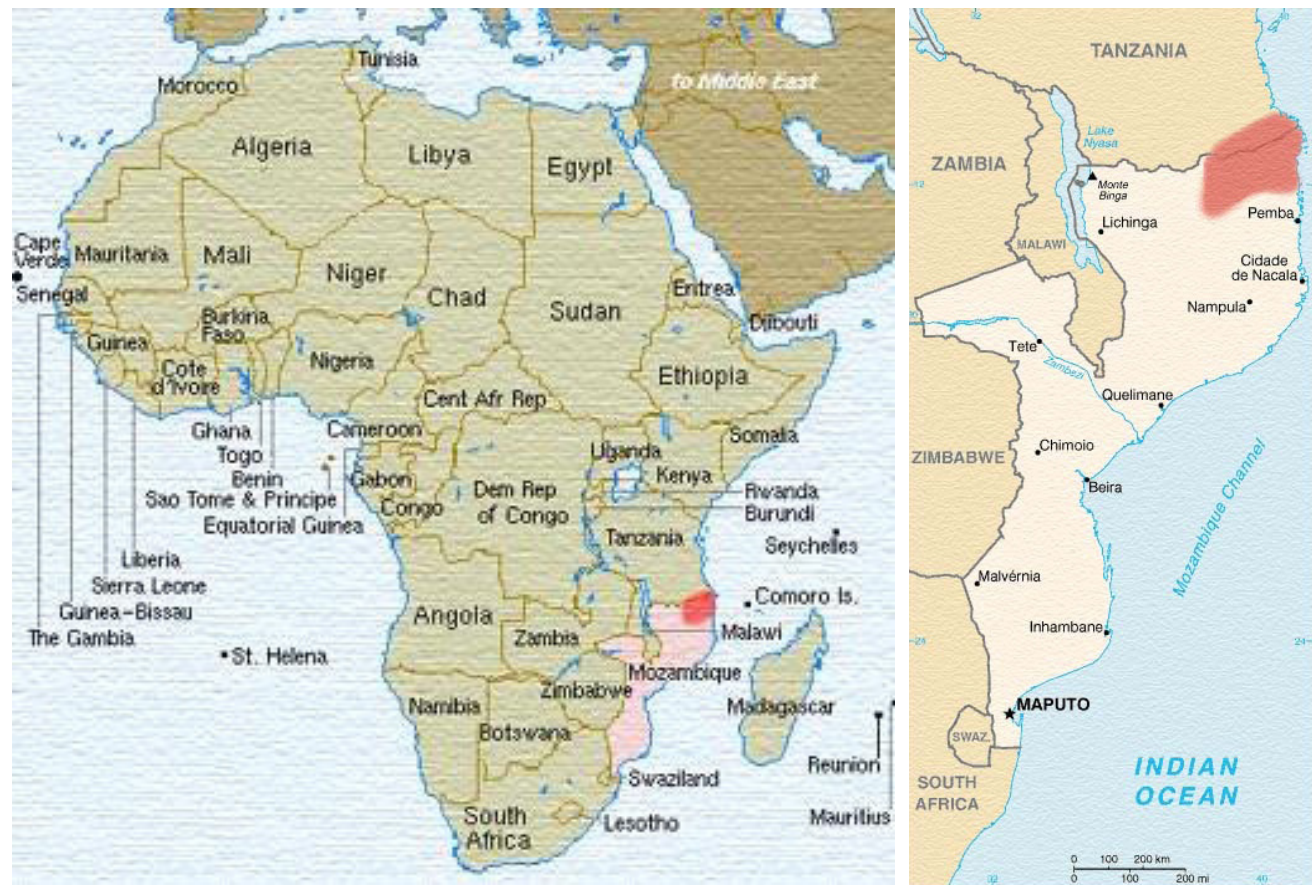

9. Fontes: <https://makonde.wordpress.com/cultura-makonde/localizacao/> e $<$ http://www.cabodelgado. gov.mz/> (respectivamente). Acesso em: 20 jun. 2017.

10. Pélissier (1994).

Figuras 1 e 2 - Mapas da África e de Moçambique com destaque em vermelho para a principal região habitada pela população makonde ao nordeste de Moçambique e sudeste da Tanzânia.?

Mawia e suas variantes, mabiha, mabia, maviha, mavia, significa "colérico", "sangue quente", "feroz", "bravio" etc. Essa denominação, aos olhos dos makonde ao sul da fronteira, ainda hoje assume uma qualificação negativa. $\bigcirc$ etnônimo mawia, portanto, não é utilizada pela população de Moçambique, que se autoidentifica como makonde, um grupo de sistema matrilinear bastante heterogêneo, formado por populações de diferentes origens que se instalaram em terras altas de difícil acesso para escapar das razias e dos comerciantes de escravos. Embora os makonde dos dois lados do rio constituam o mesmo grupo etnolinguístico, estabeleceram relações diferenciadas com grupos estrangeiros europeus e árabes -, sendo marcados por influências religiosas distintas: católica ao sul do Rovuma, e islâmica ao norte.

Planalto de Mueda está localizado próximo a Kionga, na foz do rio Rovuma, uma região disputada por Portugal e Alemanha entre o final do século XIX e a Primeira Guerra, com interesses nas suas riquezas minerais e na sua localização estratégica para o estabelecimento de um posto alfandegário. Aproximadamente um mês após a ocupação alemã, em 1894, o Estado português concedeu a administração do território a norte do rio Lúrio, limite das atuais províncias de Cabo Delgado e de Nampula, à companhia majestática nomeada Companhia do Niassa. Essa companhia privada, de capital majoritariamente britânico, por precaução, não fez investidas nos territórios makonde até pouco depois da Primeira Guerra. ${ }^{10}$ A implementação da Companhia do Niassa e do trabalho forçado nas 
11. Fonte: <http://www.hoeckmann.de/karten/afrika/ tanzania/index-en.htm $>$. Acesso em 20 jun. 2017.

12. O planalto, desde o século XVIII, constituía um local bastante protegido da invasão de estrangeiros e de grupos locais, devido às condições naturais, mas, também, às estratégias de proteção elaboradas pela população makonde. Rita-Ferreira descreve o Planalto de Mueda como um local cercado de "escarpas alcantiladas para o norte, sul \& oeste e pelo matagal espesso e impenetrável que resulta do bosque secundário, depois de a floresta primitiva ser destruída”. Rita-Ferreira (1982, p. 291).

13. Rita-Ferreira (1982).

14. Weule (2000, p. xxv).

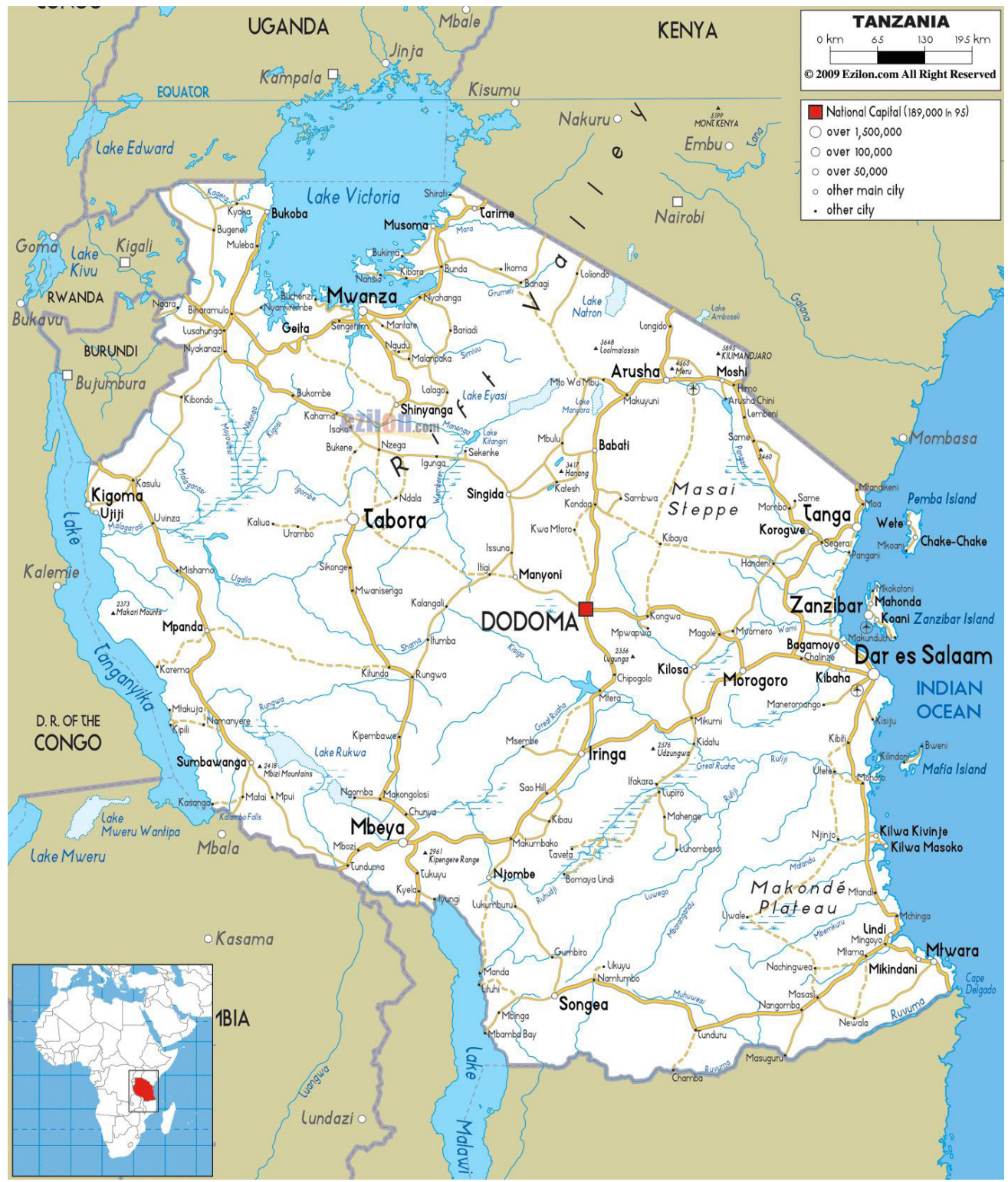

Figura 3 - Mapa da Tanzânia com delimitação do rio Rovuma ao sul, na fronteira com Moçambique. ${ }^{11}$

plantações de sisal impulsionaram o deslocamento dos makonde que comerciavam na costa para o Tanganyika e para o Planalto de Mueda. ${ }^{12}$

Desde o século XIX, os makonde de Moçambique eram conhecidos pelos europeus por sua grande resistência diante de qualquer tipo de dominação, incluindo a rejeição ao islamismo muito presente no norte do país e entre os makonde do Tanganyika. ${ }^{13}$ A partir dos relatos de Weule, Liesegang aponta que, até 1906, "os europeus tinham aparecido apenas na costa ou na margem do rio, ou percorriam as zonas baixas a sul do Rio Rovuma, como caçadores" 14 e 0 planalto permanecia protegido dessa invasão estrangeira. Os makonde de 
Moçambique encontravam-se entrincheirados em talvez 50 povoações fortificadas, conhecidas como njengo. ${ }^{15}$

Por medo de ser derrotado pelo confronto com os makonde dos planaltos de Mueda e de Macomia, o governo colonial português organizou a Campanha de Moçambique para iniciar o que ficou conhecido como "pacificação do povo makonde", levada a cabo em 1916, quando Portugal entra na Primeira Guerra contra a Alemanha. António Augusto Pereira Cabral, ${ }^{16}$ então secretário de Negócios Indígenas, descreve os makonde, juntamente com os ajaua, como as únicas "tribos" que se "conservaram insubmissas" à coluna comandada por António Maria Cardoso em passagem pelo lbo até as margens do lago Niassa. ${ }^{17}$ Tendo a Inglaterra como aliada e contando com milhares de soldados e carregadores negros de Moçambique, a maior parte deles raptados para compor as tropas portuguesas, em 1917 o Exército português reocupou Kionga e organizou a Coluna dos Macondes com o objetivo de dominar os seus territórios. Apesar de a Coluna adentrar o Planalto de Mueda em 1917 e ocupá-lo no início da década de 1920, apenas em 1929, com a perda da concessão da administração de Cabo Delgado pela Companhia do Niassa, é que finalmente a administração colonial portuguesa é implementada na região. ${ }^{18}$

A resistência histórica da população makonde se reflete não só na sua organização nas terras altas e nos enfrentamentos com as tropas portuguesas, mas também na experiência de deslocamento do sul para o norte do Rovuma, especialmente na década de 1950, em busca de melhores condições de trabalho e de vida. $\bigcirc$ fluxo da população makonde para o norte, portanto, dialoga com as estratégias adotadas pelos makonde de Moçambique com o propósito de escapar da opressão do governo colonial português, como o trabalho forçado, o pagamento de altos impostos e as perseguições. Essa experiência migratória transfronteiriça relaciona-se com novas configurações makonde da vida social, política e também artística. Assim, sob o ponto de vista desse grupo, o deslocamento espacial esteve diretamente associado à criação de associações de ajuda mútua, à formação de grupos políticos, ao desenvolvimento de ideias e planos para a libertação do domínio colonial, e à produção de esculturas. Aqui estou preocupada em compreender como, neste contexto, se estabeleceram novas redes e ambientes que permitiram a emergência de um estilo escultórico denominado shetani e envolveu a circulação de pessoas, objetos e conhecimento entre o sul e o norte do rio Rovuma, entre as décadas de 1950 e 1960.

\section{A arte makonde em Moçambique colonial}

Os makonde de Moçambique e da Tanzânia compartilham a língua shi-makonde com forte influência da língua kiswahili, a produção de máscaras de uso ritual, conhecidas como mapiko, além de objetos utilitários esculpidos e de estatuária que se tornaram emblema da cultura material desse grupo. Diversos
15. Liesegang utiliza como fonte as publicações de Ferreira (1946) e Barbosa (1970) que tratam da expedição comandada por Neutel de Abreu ao norte de Moçambique.

16. Cabral (1925).

17. Essa coluna formada por 70 soldados de origem angune, em 1885, acompanhou a expedição de Serpa Pinto ao interior de Cabo Delgado, por onde já havia passado Livingstone.

18. Entre 1894 e 1929, o Estado português concedeu a administração de Cabo Delgado e do Niassa à Companhia do Niassa, uma companhia privada de capital majoritariamente britânico, que por prudência não fez investidas na região dos makonde até pouco antes da Primeira Guerra Mundial. Pélissier (1994) 
19. Ferreirinha (1949).

20. Jorge Dias; Margot Dias (1964).

21. Margot Dias (1973).

22. O caráter confidencial desta documentação refere-se à sistematização e análise de informações reunidas por Jorge Dias nas campanhas de estudo realizadas em Angola e em Moçambique, direcionadas a Oliveira Salazar, então presidente do Conselho de Ministros, com a finalidade de contribuir na avaliação e nos ajustes da política colonial em vigor. Jorge Dias; Guerreiro (1958), Jorge Dias (1959), Jorge Dias; Margot Dias; Guerreiro (1960).

23. A glimpse (1952, p. 42).

24. A construção de aldeias cenográficas no âmbito dos museus tem forte influência das exposições coloniais realizadas na Europa. Sobre o Museu do Dundo, em Angola, ver Bevilacqua (2016), e sobre exposições que representam o Império colonial português, ver Thomaz (2002).

25. Nascidos na década de 1940, na aldeia de Nandimba (Planalto de Mueda), Ntundo e Pitamwiu aprenderam a esculpir com os artistas mais velhos Patrício Benjamim e Taunas Nyakenya, respectivamente. Embora os considerem como mestres, ambos citam diversos outros artistas mais velhos, precursores da escultura figurativa produzida no Planalto de Mueda. Dentre eles, Nyankabala, Sumaíle e Mpossa que, juntamente com Patrício Benjamim e Nyakenya, tinham suas peças vendidas na Tanzânia, mas também na capital de Moçambique, Lourenço Marques. Tanto Ntundo quanto Pitamwiu atuaram como soldados e escultores na luta de libertação de Moçambique. Ntundo (2013); Pitamwiu (2013). viajantes, etnólogos e funcionários do regime colonial português destacaram a importância dessa produção em madeira entre os makonde de Moçambique. Seus valores estéticos e artísticos foram abordados pela literatura colonial, como nos trabalhos do já citado Karl Weule (1906), do poeta e pintor português Felisberto Ferreirinha (1949), ${ }^{19}$ e também do antropólogo português Jorge Dias $(1964)^{20}$ e da etnomusicóloga alemã Margot Dias (1973)²1, dentre outros.

A relevância dessa produção artística makonde é destacada em livros, artigos, fotografias e catálogos publicados no período colonial, mas também em documentos não publicados, produzidos por pesquisadores contratados pelo governo colonial português. Como exemplo, cito os relatórios confidenciais ${ }^{22}$ de Jorge Dias (1956-1960), elaborados quando o mesmo exercia a função de chefe da Missão de Estudos das Minorias Étnicas do Ultramar Português. Sob a tônica evolucionista da etnologia portuguesa da época, tanto os relatórios quanto parte das produções bibliográficas ressaltam a respectiva produção escultórica como uma expressão coletiva, fruto de habilidades sofisticadas inerentes aos makonde. De maneira ambígua, ao mesmo tempo que esses documentos e a bibliografia traziam tais "habilidades" como características que tornavam a referida população "mais evoluída" do que outros grupos vizinhos, ela ressaltava também a marca do primitivismo associada, especialmente, à combatividade dos makonde de Moçambique diante das ameaças de dominação.

Uma ilustração do destaque às esculturas de origem makonde encontrase na publicação organizada pela Comissão para a Representação de Moçambique na exposição "Centenário de Rhodes" ou "Exposição de Bulawayo", na antiga Rodésia do Sul, realizada em 1953. Nessa publicação, produzida com o intuito de vender uma boa imagem do país para incentivar o turismo e o comércio regional e internacional, os autores equiparam as esculturas makonde com a dança orquestral dos bachopi, conhecida como a timbila, caracterizada como "a mais alta expressão artística da África Austral". Já as esculturas mencionadas são consideradas como "obras de elevado valor humano e estético" que se sobressaíam diante daquelas produzidas por outros grupos etnolinguísticos. ${ }^{23}$

Como reflexo da divulgação da centralidade dessa produção em Moçambique, no acervo do Museu Nacional de Etnologia de Moçambique (Nampula), formado a partir da década de 1950, as peças de origem makonde se destacam pela sua quantidade e diversidade em relação às peças de outras populações do país. Além dos "objetos de uso pessoal dos indígenas", outro elemento que ilustra o apelo etnográfico da instituição, com foco na população makonde, são os quiosques construídos na parte externa do museu que representavam uma "aldeia de artistas nativos", "habitada" principalmente por escultores de origem makonde 24 . Na "aldeia", os escultores podiam vender seus trabalhos a turistas e demais visitantes por preços controlados pelo museu.

A transformação da produção escultórica makonde em objeto de arte é abordada pelos escultores naturais do Planalto de Mueda. Em entrevista com os artistas Matias Ntundo e Geraldo Pitamwiu25, ambos relataram que a escultura 
produzida pelos makonde de Moçambique foi concebida como arte, dotada de valor comercial, somente a partir do contato com os portugueses. Estes passaram a encomendar modelos específicos de escultura em pau-preto, ${ }^{26}$ madeira muito mais resistente que o ntene, ${ }^{27}$ bastante leve e de cor clara, utilizadas para a fabricação das máscaras mapiko. Além das máscaras, usadas principalmente no contexto religioso dos ritos de iniciação masculinos, os objetos utilitários em madeira também atraíam a atenção dos colecionadores estrangeiros, como é o caso do mtete, denominação em shi-makonde para as tampas de frascos de medicamento. Segundo Karl Weule, ${ }^{28}$ embora também produzidas no Tanganyika, a fabricação das tampas era originária do Planalto de Mueda e, na sua opinião, correspondiam ao "mais alto grau de artesanato" da África Índica. A afirmação de Weule baseiase no rico detalhamento das formas esculpidas de figuras humanas ou de animais em pequenas tampas de aproximadamente 7 centímetros.
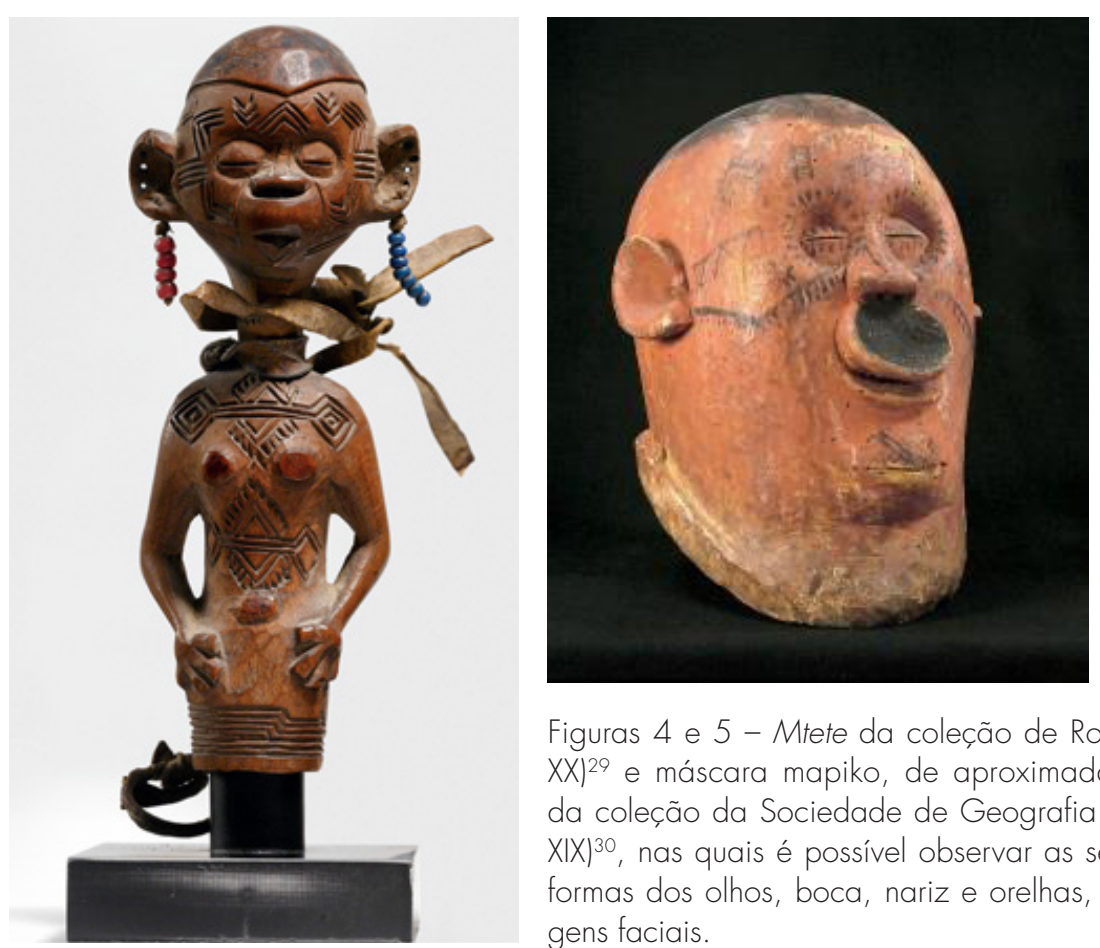

Figuras 4 e 5 - Mtete da coleção de Robert Rubin Iséc. $X X)^{29}$ e máscara mapiko, de aproximadamente $40 \mathrm{~cm}$, da coleção da Sociedade de Geografia de Lisboa (séc. $X|X|^{30}$, nas quais é possível observar as semelhanças nas formas dos olhos, boca, nariz e orelhas, além das tatuagens faciais.

Retomando ao assunto das encomendas, de acordo com os escultores Matias Ntundo e Geraldo Pitamwiu, o primeiro modelo de escultura solicitada pelos portugueses no Planalto de Mueda foram os bustos, com destaque para o de Luís de Camões, segundo Ntundo, o preferido dos funcionários coloniais, e o de Oliveira Salazar, solicitado com menos frequência. Com o aprimoramento da técnica, os dois escultores relataram que passaram a produzir figuras humanas de corpo inteiro e, posteriormente, outros modelos começaram a ser encomendados, como, por exemplo, animais e cenas do cotidiano, que caracterizam o estilo binadamu, ${ }^{31}$ objetos utilitários, figuras humanas representando os masai ou um tipo
26. Denominação utilizada em Moçambique para se referir ao ébano, uma madeira bastante densa e escura, com uma grande capacidade de polimento.

27. Termo em shi-makonde que se refere à madeira sumaúma.

28. Weule (2000).

29. Tampa de 7 a 10 centímetros exposta no catálogo da Sotheby's de 2011. Disponível em: <http://detoursdesmondes.typepad.com/ dtours_des_mondes / makonde/>. Acesso em: 15 nov. 2015.

30. Imagem disponibilizada no sítio eletrônico da Sociedade de Geografia de Lisboa. Disponível em: <http://www.socgeografialis boa.pt/?s=makonde $>$. cesso em: fev. 2016.

31. A palavra binadamu, em língua kiswahili, significa "filho de Adão" ou "humano". 
32. Fonte: $<$ http://museudaciencia.inwebonline.net/ficha.aspx?id $=6912 \&$ src $=$ antr opologia>. Acesso em: 18 abr. 2016. mais genérico que ficou conhecido como mamã africana, além de imagens associadas ao cristianismo.

O hábito de se colecionar arte makonde pelos colonos em Moçambique foi um dos assuntos recorrentes nas conversas e entrevistas que realizei com escultores durante a pesquisa de campo entre 2012 e 2014 . Parte das coleções particulares compôs, posteriormente, acervos museológicos de fora do continente africano. Esse é o caso da coleção de arte makonde do Museu Antropológico da Universidade de Coimbra, composta por 135 peças, na sua grande maioria do estilo binadamu, reunidas entre 1940 e 1974 em Moçambique por Maria Luísa da Silva e Manuel dos Santos Soares, respectivamente, radialista da Rádio de Moçambique e engenheiro técnico agrário.
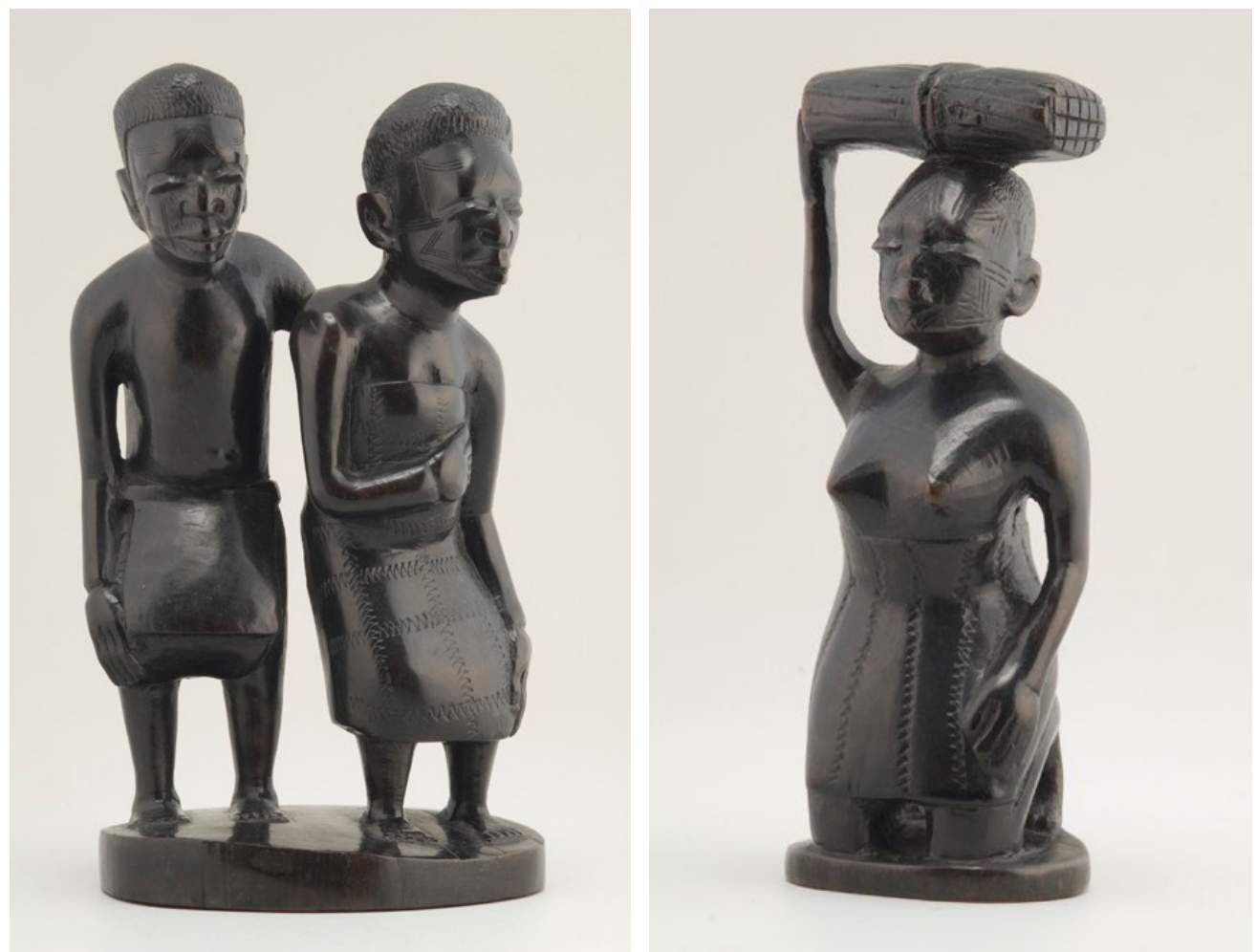

Figuras 6 e 7 - Esculturas da coleção de arte makonde do Museu Antropológico da Universidade de Coimbra. Século XX, Moçambique. ${ }^{32}$

Conforme os relatos de Ntundo e Pitamwiu, as esculturas eram vendidas aos colonos no próprio Planalto de Mueda ou, com mais frequência, levadas pelos escultores para as cidades onde havia uma maior concentração de portugueses, como Porto Amélia (atual Pemba, capital da Província de Cabo Delgado), Mocímboa da Praia e Montepuez. Pitamwiu descreve que, antes do início da guerra de independência, ele produzia individualmente em sua casa e esperava acumular aproximadamente dez esculturas para vender pessoalmente aos comerciantes portugueses nas referidas localidades de Cabo Delgado. Ao chegar 
às cidades, após longos percursos a pé, Pitamwiu relata que costumava fazer os ajustes nas peças e as levava até as lojas para serem vendidas.

A literatura confirma que desde a década de 1930 as esculturas de origem makonde já estavam sendo comercializadas devido à situação socioeconômica e política da população makonde, cujo planalto em Moçambique nesse mesmo período estava recém-dominado. De acordo com Blesse, ${ }^{33}$ como alternativa de fonte de renda, novos tipos de esculturas passaram a ser feitas com - objetivo de agradar os compradores. Ao norte do Rovuma, essas mesmas tendências ocorriam desde o final do século XIX, no entanto, lá elas não foram prosseguidas em razão de diversas mudanças sociais e culturais marcadas, especialmente, pela influência do islamismo, cuja religião, diferente do catolicismo, costuma interditar a representação da figura humana ${ }^{34}$.

Se por um lado a documentação e a literatura colonial sobre a produção escultórica de origem makonde, além dos relatos dos próprios escultores, revelam uma suposta valorização do governo colonial português e dos colonos em relação à sua aquisição, por outro lado, Jorge Dias, em seus relatórios, faz diversos apelos às autoridades portuguesas para que houvesse um melhor aproveitamento dessa arte em Moçambique. A partir da sua experiência de pesquisa no Tanganyika no final da década de 1950, Jorge Dias ${ }^{35}$ chama a atenção para a importância da produção dos escultores makonde de Moçambique no norte do rio Rovuma, onde já se encontrava estabelecido um mercado de arte makonde.

\section{Novos estilos de escultura na experiência de migração}

A atenção por essa produção material, popularmente conhecida como "arte makonde", foi ampliada entre as décadas de 1950 e 1960 com a criação no Tanganyika dos estilos de escultura: ujamaa e shetani. $\bigcirc$ termo ujamaa, em língua kiswahili, significa família ou sentimento de pertença familiar, e foi adotado na literatura, no mercado das artes e pelos próprios artistas para se referir ao estilo criado pelo escultor makonde Yakobo Sangwani, natural do Planalto de Mueda. ${ }^{36}$ Já a escultura shetani, criada por Likonkoa, também do Planalto de Mueda e contemporâneo de Sangwani, normalmente traz representações zoomórficas e antropomórficas, não naturalistas, ou representações de ambas as formas combinadas em uma mesma peça (como é possível observar na Figura 8), ou ainda, representações de formas mais abstratas. De acordo com os relatos orais que coletei em pesquisa de campo em Moçambique e com a bibliografia, as esculturas shetani representam um espírito protetor ou malévolo presente na cosmogonia makonde. ${ }^{37}$

Esses novos tipos de peça inseridos na categoria "arte makonde" tornaram-se conhecidos também como "escultura makonde moderna" ou "escultura moderna makonde", a partir da classificação publicada por Anthony Stout em 1966. ${ }^{38}$ Nessa mesma década, as esculturas shetani encontravam-se inseridas em
33. Blesse (1984).

34. Margot Dias (1973), Grohs (1971).

35. Dias (1959).

36. Essa escultura originalmente foi batizada como dimongo, termo derivado da palavra imongo, que em língua shi-makonde significa força, vigor, energia. Em referência a esse estilo de escultura, também eram utilizadas denominações derivadas, como "árvore da vida", "árvore da família" ou "torre da família”, em razão da sua estrutura: uma ou mais pessoas na base apoiam outras, e essas, por sua vez, sustentam outras e a si próprias, e assim por diante. A escolha do novo nome ujamaa, na década de 1960, confluía com a ideologia do ujamaa vijiji$n i$, ou "socialismo de aldeia”, recém-criada por Julius Nyerere. Shule (2010).

37. De acordo com Margot Dias, Karl Weule foi o primeiro a citar o termo sheta$n i$ em referência à produção escultórica makonde, mais especificamente às mascaras faciais com chifre produzidas no Tanganyika. Elas foram denominadas por Weule como "máscaras do Diabo", pelo fato do termo em kiswahili ser derivado da palavra árabe shaitan, traduzida muitas vezes como satanás. Dias (1973).

38. Stout (1966). 
39. Registro da autora.

40. Adam (1993).

41. O episódio emblemático na história de Moçambique conhecido como "Massacre de Mueda" foi consequência do encontro entre alguns membros de associações makonde instaladas no Tanganyika, o administrador colonial de Mueda e o governador de Cabo Delgado. O encontro, marcado no dia 16 de junho de 1960, tinha como propósito discutir o retorno da população makonde emigrada e a questão do aumento do valor pago pelos produtos agrícolas do planalto. Essa tentativa de negociação resultou na prisão dos representantes das associações mencionadas e no massacre de vários camponeses na frente do prédio da administração de Mueda, sob o comando do administrador e do governador, com a força bélica da tropa militar portuguesa. Laranjeira (2016). galerias de arte da Tanzânia, coleções de arte africana e em exposições sediadas especialmente na Alemanha, França, Estados Unidos e Japão.

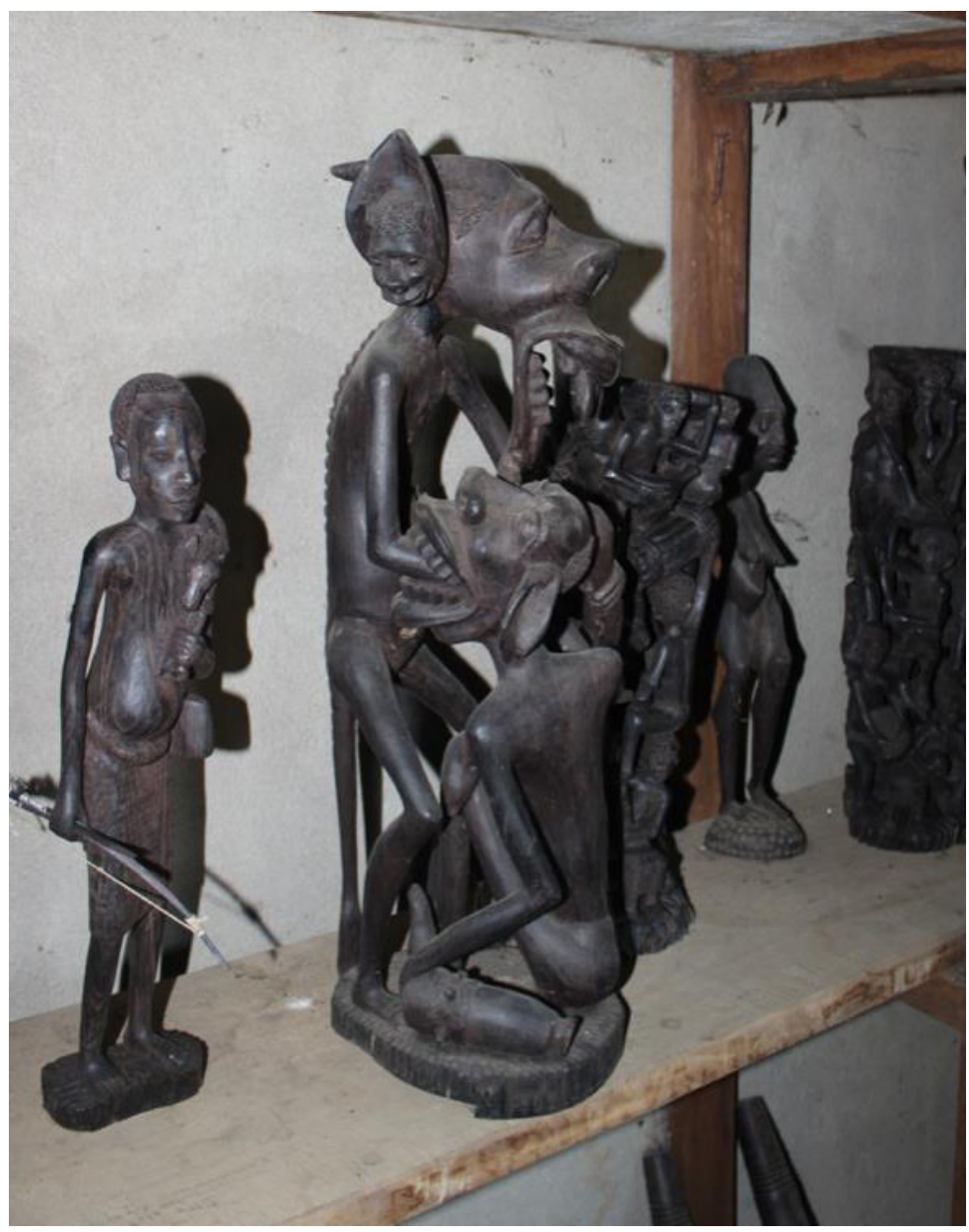

Figura 8 - Escultura shetani na loja da associação de escultores de Nandimba em contraste com peças de outros estilos (Planalto de Mueda/Moçambique). ${ }^{39}$

Embora a criação das esculturas ujamaa e shetani no Tanganyika se relacione com a experiência de migração dos makonde de Moçambique para o norte do rio Rovuma, é importante destacar que, desde a ocupação colonial do Planalto de Mueda na década de 1920, o deslocamento desse grupo para outras regiões de Moçambique e para o Tanganyika se tornou constante. Entre as décadas de 1930 e 1950, milhares de camponeses de origem makonde atravessaram o Rovuma para se instalar no Tanganyika. ${ }^{40} \mathrm{Na}$ década de 1950, quando Moçambique e outras colônias portuguesas tornaram-se "províncias ultramarinas", esse movimento se acentuou, dentre outros motivos, devido ao aumento dos impostos e do controle violento por parte do governo colonial. O Massacre de Mueda, ${ }^{41}$ a formação da Frente de Libertação de Moçambique (Frelimo) e o início da guerra pela libertação 
de Moçambique, na primeira metade da década de 1960, impulsionaram uma nova corrente migratória para o Tanganyika, independente desde 1962.

De acordo com publicações oficiais do Tanganyika, expostas no relatório da Campanha de 195942 da Missão de Estudos das Minorias Étnicas do Ultramar Português, comandada pelo antropólogo Jorge Dias, em 1958 havia 27.489 makondes emigrados de Moçambique. Para Dias, essa situação era ainda mais alarmante porque, até então, se estimava haver 100.000 makondes vivendo em Moçambique. Portanto, de acordo com tais dados, aproximadamente 30\% dessa população encontrava-se fora do país. $\bigcirc$ autor, expressando sua posição de colaborador do regime colonial, afirma que a maior parte das pessoas emigrava por razões econômicas, já que haveria pouca oportunidade para se ganhar dinheiro em Moçambique, tendo em vista a escassez de indústrias e de empresas agrícolas no norte do país. De maneira sutil, Dias expõe que o trabalho não remunerado nas plantações de sisal também contribuía para a expressividade desse deslocamento. Os relatos orais coletados em pesquisa de campo, contudo, revelaram que, para além da questão econômica, a violência do regime colonial era um fator primordial para essa corrente migratória.

Assim, a população makonde de Moçambique, que já tinha o hábito de transitar pelo Tanganyika para vender seus produtos agrícolas (como o amendoim e o milhol por um preço mais alto e ter acesso a produtos manufaturados mais baratos (como tecidos, ferramentas, rádios etc.), especialmente na década de 1950, passou a se fixar ao norte do Rovuma para trabalhar nas plantações de sisal ou, de forma autônoma, na produção de esculturas. Embora os impostos no Tanganyika fossem mais altos, eles podiam ser pagos em prestações com o salário que a população makonde não recebia em Moçambique trabalhando de maneira forçada nas plantações. ${ }^{43}$ Segundo o historiador moçambicano Yussuf Adam, ${ }^{44}$ a dependência pelo trabalho migratório predominante na economia colonial pautavase na falta de oportunidades oferecidas pelas machambas ${ }^{45}$ pessoais.

Os relatos coletados em pesquisa de campo revelam que a produção na machamba era conciliada muitas vezes com a atividade da escultura em paupreto, cujo comércio, entre as décadas de 1950 e 1960, estava em ascendência no Tanganyika. Após viverem as limitações de produção de renda e a violência colonial em Moçambique, a experiência de produzir em lugar e contexto diferentes, com acesso inédito à urbanização e à industrialização, e com menor controle por parte do poder colonial e dos compradores, possibilitou a criação de estilos escultóricos distantes das representações figurativas mais comuns na escultura de origem makonde. ${ }^{46}$ Esses novos estilos de escultura, portanto, fugiam das formas habituais das figuras humanas e animais esculpidas em pau-preto e foram inseridas no mercado das artes da Tanzânia no final da década de 1950 e início da de 1960. Essas esculturas, muitas vezes, eram levadas ao litoral de Mtwara e de Dar es Salaam para serem vendidas aos marinheiros europeus, intermediários nas vendas aos colecionadores e galeristas, e depois passaram a ser destinadas também às galerias e lojas de arte e artesanato dos centros urbanos locais.
42. Jorge Dias; Margot Dias; Guerreiro (1960).

43. Adam (1993).

44. Adam (1993).

45. Pequena propriedade agrícola voltada, especialmente, para a produção familiar.

46. Blesse (1984). 


\section{Kasfir (1992).}

48. Kingdon (2002).

49. A abadia beneditina de Ndanda foi construída na cidade de Ndanda, ao sudeste da Tanzânia, em 1906. No final dos anos 1960, a missão de Ndanda era responsável pela construção de aproximadamente 40 paróquias, 220 estações missionárias, 200 escolas primárias, 3 hospitais e 22 dispensários, 6 escolas de ensino médio e a Escola Abadia de Ndanda. Fonte: $<$ http://ndanda.org $>$. Acesso em: 12 jan. 2016.

\section{A escultura shetani na trajetória de Samaki Likonkoa}

No intuito de elucidar o processo de criação da escultura shetani, o impacto provocado no mercado de arte makonde do Tanganyika, assim como o contexto histórico e social da experiência migratória da população makonde de Moçambique no norte do rio Rovuma, trago a seguir a trajetória de Samaki Likonkoa, baseada nos relatos da pesquisadora Sidney Kasfir ${ }^{47}$ e do pesquisador e curador Zachary Kingdon. ${ }^{48}$

Samaki nasceu em Diaca, no Planalto de Mueda, e provavelmente migrou para Mtwara, ao sul do Tanganyika, no início da década de 1950. Em Mtwara, trabalhou no porto por um ou dois anos até ser recrutado para o trabalho nas plantações de Norman Kirk em Mahurunga, ao sudoeste da Tanzânia e próximo do rio Rovuma. Nascido na Nova Zelândia, Kirk era proprietário de plantações de limão e caju e foi um dos primeiros a enveredar pelo comércio de arte makonde no Tanganyika no início da década de 1950. Assim, conforme relata o filho do escultor, Mbalika Samaki, quando Kirk se tornou também um comerciante de arte makonde, seu pai, Samaki Likonkoa, começou a aprender a arte da escultura em pau-preto com Likenikeni Sabini, que trabalhava na escola-oficina para carpinteiros e escultores da Missão de Ndanda ${ }^{49}$ no distrito de Masasi. No final da década de 1950, Kirk, sem abandonar o comércio agrícola, passou a comprar regularmente peças levadas pelos escultores até sua casa. Dessa forma, comprando e vendendo esculturas produzidas por artistas de origem makonde, Kirk constituiu um negócio bastante rentável, especialmente com o comércio dos jogos de xadrez esculpidos em madeira, idealizado por ele.

As suas peças, conforme a descrição do comerciante de esculturas Mohamed Peera, tornaram-se mais arredondadas, com mais movimento e menos naturalistas, a partir da representação do shetani. A criação de Samaki é percebida por Zachary Kingdon como uma das inovações mais radicais e importantes da história da produção escultórica de matriz makonde. Para esse autor, o impacto do novo estilo de peça não se restringia a uma questão estética, mas também ao mercado e mais especificamente à relação entre o comerciante e o artista. O shetani foi inserido no mercado das artes comandado pelos irmãos Peera em Dar es Salaam com sucesso em um momento de impasse e de crise na relação entre patrono e escultor. As novas formas das peças de Samaki, distantes das esculturas naturalistas já conhecidas no mercado de arte africana de Moçambique e do Tanganyika, representadas pelos binadamu, serviram como inspiração para outros escultores que produziam na loja e oficina do comerciante de origem indiana Mohamed Peera, um dos primeiros a se especializar no comércio de arte makonde em Dar es Salaam. Até o surgimento do shetani, a loja frequentada especialmente por turistas era especializada em estatuetas e cabeças do tipo masai em madeira, objetos utilitários em pau-preto e em marfim, além de joias em ouro, produzidas na própria loja por um ourives do Ceilão e em esculturas makonde do tipo binadamu. 
Mohamed, um dos proprietários, já tinha o desejo de vender peças mais artísticas e certa vez foi procurado pelo escultor de origem makonde Manguli Istiwawo, em busca de trabalho na sua loja. Conforme a entrevista realizada por Kingdon com Mohamed Peera, o comerciante confirmou se de fato Manguli era escultor ao perguntar se ele possuía as ferramentas de trabalho. Com a resposta positiva e uma prova da sua produção, no dia seguinte, Manguli passou a produzir exclusivamente para Mohamed no quintal da sua loja. Em poucos meses havia oito escultores de origem makonde dividindo a área externa do estabelecimento e trabalhando exclusivamente para os irmãos Peera. A descrição de Mohamed sobre as primeiras peças feitas por Manguli no novo espaço de trabalho ilustra o perfil das esculturas vendidas na loja e nos vilarejos antes da criação de Samaki: um homem fumando um cachimbo de água e uma mulher pilando milho. Ambas as figuras eram bastante habituais no repertório das esculturas conhecidas como binadamu.

No entanto, de acordo com Mohamed Peera, ele pagava mais caro pelas peças que revelavam maior expressividade e diferença em relação a um padrão já estabelecido. Isso motivava os escultores a criarem novos temas de trabalho, ainda que sempre no estilo binadamu, como dançarinos, lutadores, caçadores e escultores em atividade e mulheres em tarefas domésticas. Após vender diversas peças de origem zaramo para um comerciante de Nova York e saber do seu grande interesse pelas esculturas de origem makonde, Mohamed passou a fazer um estoque com a produção dos artistas que trabalhavam em sua loja. $\mathrm{Na}$ perspectiva de vender as peças para esse comprador e de ter no seu estoque esculturas mais diferenciadas e, acrescento aqui, com maior valor comercial, Mohamed passou a estabelecer um diálogo mais próximo com os artistas que se destacavam na produção escultórica. ${ }^{50}$

Nessa aproximação com os escultores, Mohamed também foi ao encontro de peças que agradavam mais a seu gosto pessoal, escapando da padronização das esculturas que costumavam ser vendidas em sua loja. Percebeu, dentre os artistas com quem tinha contato mais próximo, que eles se recusavam a fazer cópias de outras esculturas, algo muitas vezes solicitado pelo comprador ou pelo patrono, visto que o tema e as formas das peças variavam de acordo com sua inspiração. Sobre a impossibilidade de garantir vantagem na venda com a cópia das esculturas mais compradas, Mohamed relata que um amigo, na tentativa de alertá-lo de que poderia se tornar milionário, comentou sobre os escultores da África atlântica, que ganhavam muito dinheiro. A sugestão do amigo era a de que Mohamed encomendasse aos escultores makonde a reprodução dessas peças já conhecidas nas coleções de arte africana presentes na Europa e nos EUA. Assim, o amigo mostrou para Chanuo, um artista que trabalhava com Mohamed, a imagem de uma escultura da Nigéria que representava um cavaleiro. $\bigcirc$ artista fez duas cópias da escultura fotografada e, na terceira, Chanuo esculpiu o cavalo rindo, com a cabeça voltada para o cavaleiro. A partir desse episódio, Mohamed confirmou que seria impossível fazer fortuna solicitando cópias aos escultores makonde e investiu na ampliação do repertório de estilos de peças vendidas em sua loja.
50. A aproximação de Mohamed em relação aos escultores de origem makonde da região envolveu também os artistas do Planalto de Mueda que haviam emigrado para o Zanzibar e passaram a viver na Tanzânia após o sultão do Zanzibar expulsar, entre $1961 \mathrm{e}$ 1963, os tanzanianos, incluindo os makonde nascidos em Moçambique, sob a acusação de participarem dos partidos políticos Afro-Chirazi. Kingdon (2002); Rich (2012). 
51. Kingdon (2002, p. 80).

52. Kangai; Mupondi (2013).

53. Kingdon (2002).

54. Kasfir (1992), em outra versão sobre a criação do estilo shetani, descreve que, certo dia, Samaki carregava uma escultura do tipo binadamu para o comerciante de arte Mohamed Peera em Dar es Salaam, quando um dos braços da figura humana esculpida quebrou acidentalmente no caminho. Ao retornar para casa, Samaki sonhou que seu pai morto o alertava para suavizar a base dos ombros e tirar os olhos, passando a representar, assim, um espírito do mato, conhecido como djinn, em língua shi-makonde, e como shetani, em kiswahili.
Na tentativa de superar a dificuldade da venda das peças de Samaki, descrita por Mohamed como reproduções das conhecidas binadamu com formas mais estáticas, o comerciante desafiou o artista a "aperfeiçoar o seu estilo". ${ }^{51} \mathrm{~A}$ interferência do comerciante na criação das peças e formas a serem seguidas pelos escultores é um aspecto sublinhado por Kingdon, mas também por Kangai e Mupondi. ${ }^{52}$ Nas suas recolhas e compras de esculturas nos vilarejos próximos a Dar es Salaam, Mohamed Peera costumava dar sugestões aos artistas em relação a formas e estilos a serem produzidos de acordo com os interesses dos compradores que frequentavam a sua loja. A relação de poder entre comerciante e artista e a manipulação exercida pelo primeiro em relação ao segundo podem ser ilustradas com o relato de Mohamed Peera sobre o conselho dirigido a Samaki em um contexto marcado pela dificuldade da venda de suas peças. Segundo Mohamed, ele chegou a dizer a Samaki que ele deveria abandonar o trabalho com a escultura e voltar à atividade que exercia antes nas plantações de Kirk. ${ }^{53}$

Conforme os relatos de Mohamed, Samaki, no entanto, insistiu na tentativa de mudança e depois de uma ou duas semanas mostrou a ele outras peças binadamu junto com outra completamente diferente. Essa escultura apresentava uma figura humana com o tronco e a cabeça arredondados, dois olhos redondos, uma boca e duas pernas finas presas numa base circular. Mohamed relata que pagou sete xelins pela peça, o equivalente a um dólar, e apostou na possibilidade de venda. A peça, que seguia um estilo nunca antes visto pelo comerciante, foi colocada sobre uma prateleira da loja ocupada só com esculturas makonde e foi vendida na mesma tarde.

Ortista, então, revelou que aquela peça era denominada shetani e com o estímulo de Mohamed passou a fazer outras esculturas do mesmo tipo, o que, segundo o comerciante, trouxe entusiasmo, fluidez e liberdade à produção de Samaki. ${ }^{54}$ Mohamed relata que incentivou outros artistas a fazerem suas próprias versões do shetani e isso o motivou a abrir, em 1961, um novo espaço de produção e de venda: um armazém com um quintal em Chang'ombe, na região de Dar es Salaam, onde se instalaram mais de vinte escultores de origem makonde. A maior parte desses escultores era formada por homens naturais do Planalto de Mueda que aprenderam a esculpir na Tanzânia, onde se especializaram no estilo shetani. Alguns deles, como salienta Mohamed, produziam suas peças observando, comentando e dando sugestões sobre a produção dos artistas que dividiam o mesmo espaço.

5. Considerações sobre a autonomia na produção do shetani e o seu comércio

A escultura shetani nos faz pensar sobre a relação artista-comerciante, mas também sobre a autonomia criativa do artista e a questão da autoria. Se no período pré-colonial a produção de objetos imbuídos de carga simbólica e funções rituais, como certas estatuetas, máscaras, bastões etc. estava ligada a um sistema 
controlado por autoridades políticas e religiosas locais, no período colonial os escultores de origem makonde, no Tanganyika, tinham como principais fomentadores de produção as missões religiosas e os patronos de arte. Por um lado, esses agentes impulsionaram o estabelecimento de um mercado de arte makonde, especialmente no Tanganyika, pela sua possibilidade de consolidação nos centros urbanos por onde transitavam turistas, colecionadores e demais interessados pela arte local. Por outro lado, o interesse comercial dos referidos agentes influía diretamente nas escolhas dos tipos de peças a serem produzidos. Enquanto as missões religiosas orientavam a produção de objetos em madeira, como castiçais, taças, crucifixos etc., os patronos encomendavam aos escultores peças com temas previamente definidos associados à sua própria cultura, a exemplo do jogo de xadrez, ou à cultura de grupos locais, como a figura da mulher pilando o milho, sempre em formas naturalistas, também preestabelecidas.

controle da produção dos artistas makonde, seja ela ligada ao estilo binadamu ou dos objetos de cultos cristãos e bustos de figuras representativas do Império português, e a passagem, não excludente, para a "arte makonde moderna", representada pelo shetani e pelo ujamaa, dialogam com o tema da autonomia da arte, elaborado pioneiramente por Immanuel Kant. ${ }^{55} \mathrm{~A}$ recusa nas representações figurativas sacras e ostentatórias, seguindo padrões definidos, encomendadas pela aristocracia italiana, assim como o questionamento da referencialidade, foram possíveis com a emergência de uma burguesia consumidora de arte e a consequente formação de um mercado voltado para ela. Essa mudança de paradigma envolveu a liberdade para se adotar novas formas de representação a partir de estilos pessoais, fugindo de antigos padrões estabelecidos e abrindo o caminho para a arte não representativa ou a arte abstrata propagada no século XX. ${ }^{56}$

Apoiada nessa perspectiva, considero que a consolidação de um mercado de arte makonde no período de transição para a independência do Tanganyika possibilitou o desenvolvimento da autonomia criativa, que contemplava o estilo e a inspiração do artista para a construção de suas obras. Além da autonomia criativa, destaco a autonomia comercial atingida nesse processo de mudança, já que grande parte dos artistas passou a produzir independente de missões religiosas e de patronos ricos, como Mohamed Peera. Conforme aponta Margot Dias, a arte sempre esteve "numa certa dependência da situação socioeconômica dos povos, ou da 'classe' dos artistas". 57 No entanto, a autora ressalta que essa relação de dependência não comprometeria, necessariamente, a força criadora do artista, como seria o caso da produção de arte makonde.

A partir do estilo shetani, os artistas experimentaram expressar livremente suas poéticas e traços pessoais, conservando o que Lima, 58 baseado em Simmel, denomina como "germe anímico". Portanto, as experiências de vida e os sentimentos que contaminam a produção do artista. Nessa mesma direção, as novas formas expressas na arte makonde moderna, ao romperem com o naturalismo do binadamu, mantiveram o "germe anímico", ao mesmo tempo que provocaram estranhamento e atração ao receptor. Esses aspectos, por sua vez, são valorizados 
59. Uma das lideranças da comunidade makonde do Bairro Militar, em Maputo, relata que, no ateliê de esculturas de seu avô e tio-avô, no Tanganyika, passavam compradores brancos e negros naturais do país.

60. Fonte: <http://www.tanzanianfineart.com/ $>$. Acesso em: 18 abr. 2016.61. Sally Price (2000), James Clifford (1994).

61. Sally Price (2000), James Clifford (1994). 62. Kasfir (1992). por galeristas, curadores, colecionadores, pesquisadores e consumidores de arte em geral. Dessa forma, a autonomia da arte moderna makonde não a libertou da lógica do mercado, ao contrário, ampliou as suas possibilidades de compra, de venda e de circulação. As peças de origem makonde, que nos primeiros anos da loja de Mohamed eram destinadas especialmente a um comerciante estadunidense, com a mudança significativa de estilo passaram a ser comercializadas não só em lojas de curiosidades ou arte local "tradicional" no contexto do turismo, mas em espaços diversos, incluindo as próprias oficinas dos artistas acessadas também por uma elite local emergente na Tanzânia recém-liberta do jugo colonial. ${ }^{59}$

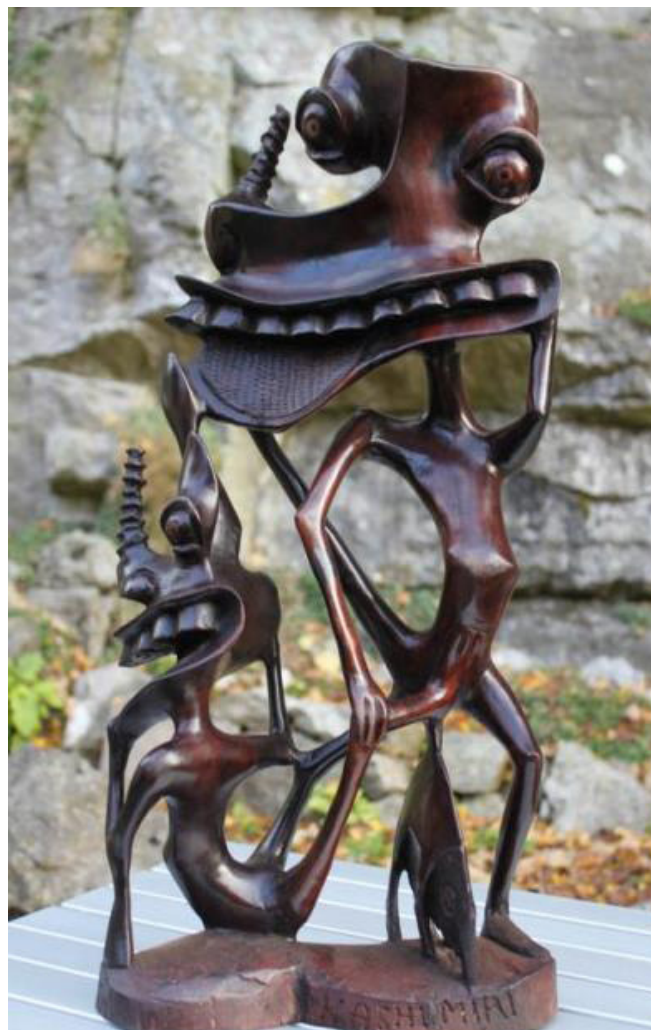

Figura 9 - Shetani do artista Kashmiri na galeria Tanzanian Fine Art. 60

As esculturas ujamaa e shetani ilustram como os temas das esculturas makonde e suas classificações usuais, como "tradicional" e "moderna", são apresentados de forma complexa e relacionam-se diretamente com a conjuntura social, religiosa, econômica e política da sua produção. As esculturas mais naturalistas, as sátiras dos personagens coloniais, as figuras humanas em cenas do cotidiano ou os objetos de cultos cristãos seguem temas atrelados à realidade colonial e são normalmente classificadas na produção bibliográfica como "arte tradicional". Esta categoria decorrente do próprio olhar colonial europeu, tal qual a noção de "arte primitiva"bl, é expressão de um contexto de encontros, estranhamentos e traduções voltados também para o mercado de arte internacional. A atualidade dos temas se relaciona tanto com uma demanda específica inerente 
ao contexto colonial, como é o caso do binadamu, quanto com a presença de novos personagens do regime colonial e com novas necessidades de expressar sua crítica social.

shetani e o ujamaa, que representam novas formas de esculturas, podendo ser traduzidas como mais modernas por romper com os padrões mencionados, por sua vez, dialogam com temas da cosmogonia da população makonde. Ao mesmo tempo, a propagação desses tipos de escultura no mercado de arte makonde está ligada diretamente à transição política provocada pela libertação colonial e à formação de uma unidade nacional no Tanganyika. Portanto, as referências a temas mais conceituais, produzidas por escultores do Planalto de Mueda no Tanganyika, surgem na guinada pelo interesse comercial das peças de origem makonde e a sua inserção em museus, galerias e exposições em diferentes países.

Como aponta Kasfir, ${ }^{62}$ os espíritos da natureza evocados nos rituais de iniciação e presentes na tradição oral da população makonde são representados pela escultura shetani produzida, sobretudo, para compradores dos centros urbanos, como é o caso de Dar es Salaam. Kasfir relaciona tal interesse e estranhamento diante das esculturas shetani com a imagem difundida pelos seus principais escultores. Como mencionado anteriormente, no período da propagação dessas esculturas, e ainda hoje, a população de origem makonde natural de Moçambique era reconhecida por uma suposta ferocidade, inscrita nas tatuagens faciais e nos dentes limados, combinada, no entanto, a uma suposta "habilidade nata" na arte escultórica.

É importante salientar que a amplitude das possibilidades de venda de esculturas com a consolidação de um mercado de arte makonde voltado para os novos estilos não expressa um rompimento com os estereótipos que permeavam as narrativas sobre a população makonde desde o século XIX e, consequentemente, sobre a arte que carregava essa identificação. Contrariamente, na tentativa de se valorizar a arte makonde moderna, atingindo um maior número de pessoas interessadas e de compradores, destacava-se o caráter "exótico" do grupo etnolinguístico associado aos artistas produtores. $\bigcirc$ mercado de arte makonde alternativo ao comércio de uma produção estandardizada e de fácil consumo apelava para a venda de peças mais autorais direcionada a um público com disposição a pagar mais caro pelas mesmas. Na Europa, por exemplo, a valorização da arte makonde moderna se mostra tanto pela exotização dos makonde de Moçambique pautada na imagem de povo agressivo e combativo, quanto pela sua presença nas grandes coleções de arte africana e do seu estilo autoral.

$\bigcirc$ shetani, portanto, não rompe com imagens associadas à produção de uma arte tradicional africana ou makonde, representada pelas máscaras mapiko, por exemplo, e interpretada pelos autores portugueses do período colonial como obra de um povo de "espírito agressivo". Essa imagem, propagada amplamente na literatura e na tradição oral, a partir da marca do etnônimo mawia, é identificada na divulgação de uma exposição voltada para o comércio de obras de arte 
63. Margot Dias (1973, apêndice, $\mathrm{s} / \mathrm{n}$ )

64. Leite (2015, p. 9). makonde consideradas modernas em uma galeria de Munique, na Alemanha. $\bigcirc$ cartaz da exposição, divulgado na ocasião de uma "semana de arte africana" em 1972, foi publicado e traduzido por Margot Dias ${ }^{63}$. Nele, junto a uma imagem de uma escultura shetani, lê-se:

ESCUITURAS MACONDE

-Criadas por nativos

-Coleccionadas por peritos!

Foi-nos possível arranjar mais uma remessa destas obras de arte.

Os Macondes habitam o planalto entre Moçambique e Tanzânia; eles pertencem à raça banto, adornam os seus corpos com escarificações e são chamados pelos vizinhos "Mawia", os irascíveis.

As suas imagens são de uma força expressiva sem par.

O escultor maconde não trabalha segundo um modelo, ele deixa livre curso à sua fantasia criadora e recria sempre obras inéditas. Cada imagem é uma peça única e consequentemente valiosa.

Se na Europa essa relação entre o tradicional e o moderno é ressaltada no intuito de fomentar a venda das peças, em Moçambique, no mesmo período, as esculturas makonde consideradas modernas, tais como o shetani, não encontraram espaço de circulação. Como aponta Pedro Pereira Leite, o movimento modernista, mesmo tendo incorporado parte do legado estético africano, "é absorvido e aplicado enquanto categoria de pensamento de forma lenta" pelo pensamento colonial português. ${ }^{64}$ A negação da autonomia estética do outro envolvia necessariamente a manutenção da posição de subordinação em relação ao poder colonial expresso nos estudos sobre a produção de arte em Moçambique. Eles revelam a lógica de que as "habilidades dos indígenas" deveriam ser colocadas a serviço do projeto colonial a partir da produção de esculturas que à população portuguesa interessava possuir, inclusive nas suas instituições voltadas para a cultura material local. Esse é o caso do Museu de Nampula, fundado em 1956, com a predominância de artefatos de origem makonde em sua coleção etnográfica.

A conjuntura política e comercial do Tanganyika do final da década de 1950 e início da de 1960 deu apoio à produção da arte makonde moderna e a sua expansão, possibilitando aos escultores a conquista de uma autonomia estética e comercial. No início da década de 1960 muitos escultores vendiam suas peças diretamente aos compradores interessados. Contudo, a autonomia estética na produção de arte makonde moderna era algo distante das análises e descrições da maior parte dos autores portugueses que tratavam sobre a arte produzida em Moçambique durante o período colonial. Uma exceção é Margot Dias, citada anteriormente, que, embora de origem alemã, estava inserida no âmbito de produção de conhecimento voltado para o regime colonial português. 
A recusa pelo reconhecimento da arte moderna makonde em Moçambique estava ligada ao contexto da sua produção, portanto, à migração em massa da população makonde para o Tanganyika na década de 1950. Além disso, a questão de essa arte ter como berço um espaço alternativo de sobrevivência e de melhores condições de vida da população makonde, somada às relações políticas desse grupo com o movimento pró-independência do Tanganyika e com associações contrárias ao jugo colonial português, também influenciou na invisibilidade da arte makonde moderna em Moçambique.

Os relatórios de Jorge Dias ${ }^{65}$, dentre outros documentos, sinalizam que uma das grandes preocupações das autoridades portuguesas em relação à migração makonde em massa para o Tanganyika girava em torno da articulação política do grupo com o Tanganyika National African Union (Tanu) e com o seu líder Julius Nyerere. Nesse contexto, a propagação das formas modernas da escultura makonde em Moçambique ou em Portugal, além de restrita, pelos motivos mencionados, faria alusão a uma possível ameaça à estabilidade da dominação colonial no norte de Moçambique.

Os mesmos relatórios, no entanto, sinalizam outros riscos relacionados ao controle efetivo da população makonde de Moçambique, como o acesso inédito do grupo a bens de consumo e à modernidade das plantações e dos centros urbanos do norte do Rovuma, como as máquinas presentes nas atividades laborais e as salas de cinema. Em última instância, a modernidade do campo e dos centros urbanos do Tanganyika representava uma ameaça no contexto de um possível retorno da população makonde residente no Tanganyika para o norte de Moçambique, marcado pela situação de extrema pobreza e vulnerabilidade social sustentada pelo regime colonial português.

Este estudo trouxe à tona a produção de arte makonde enquanto um dos aspectos de resistência da população makonde pautada na autonomia diante do poder colonial. Os artistas makonde escapavam do trabalho forçado em Moçambique ao se dedicarem às esculturas no Tanganyika, ao passo que adquiriam condições sociais menos frágeis com a venda de suas produções e uma liberdade, ainda que restrita, inédita frente à dominação colonial portuguesa. $\bigcirc$ novo ambiente político e social do Tanganyika refletiu na produção escultórica dos artistas de origem makonde do Planalto de Mueda, tanto na criação de formas e estilos novos, quanto no comércio de suas peças. $\bigcirc$ estudo do shetani, ao mesmo tempo que destaca o protagonismo dos makonde do Planalto de Mueda na criação artística no contexto de migração e na busca por autonomia, possibilita-nos pensar em outros contextos de produção da arte africana e sua relação com regimes políticos, constituição de mercados, e circulações de pessoas e ideias. 


\section{REFERÊNCIAS}

\section{FONTES IMPRESSAS}

DIAS, Jorge; GUERREIRO, Manuel Viegas. Missão de Estudos das Minorias Étnicas do Ultramar Português. Relatório da Campanha de 1957 (Moçambique e Angola). Lisboa: Centro de Estudos Políticos e Sociais da Junta de Investigações do Ultramar, 1958.

DIAS, Jorge. Missão de Estudos das Minorias Étnicas do Ultramar Português. Relatório da Campanha de 1958. Centro de Estudos Políticos e Sociais da Junta de Investigações do Ultramar. Lisboa, 1959.

; DIAS, Margot; GUERREIRO, Manuel Viegas. Missão de Estudos das Minorias Étnicas do Ultramar Português. Relatório da Campanha de 1959 (Moçambique, Angola, Tanganhica e União Sul-Africana). Lisboa: Centro de Estudos Políticos e Sociais da Junta de Investigações do Ultramar, 1960.

\section{LIVROS, ARTIGOS E TESES}

A GLIMPSE of Moçambique. Lourenço Marques: Repartição Técnica de Estatística; Governement Printing Works, 1952, p. 42.

ADAM, Yussuf. Mueda, 1917-1990: Resistência, colonialismo, libertação e desenvolvimento. Arquivo: Boletim do Arquivo Histórico de Moçambique, Maputo, n. 14, p. 9-102, out. 1993. Edição especial Cabo Delgado.

BEVILACQUA, Juliana Ribeiro da Silva. De caçadores a caça: sobas, Diamang e o Museu do Dundo. São Paulo, 2016. Tese (Doutorado) - Faculdade de Filosofia, Letras e Ciências Humanas, Universidade de São Paulo.

BLESSE, Giselher. Moderne Makondeplastik: Kunst aus Ostrafrika. Leipzig: Museum fur Völkerkunde zu Leipzig, 1984. Catálogo.

CABRAL, António Augusto. Raças, Usos e Costumes dos Indígenas da Província de Moçambique por António Augusto Pereira Cabral Secretário dos Negócios Indígenas. Lourenço Marques: Imprensa Nacional, 1925.

CLIFFORD, James. Colecionando arte e cultura. Revista do Patrimônio, n. 23, 1994. 
DIAS, Jorge; DIAS, Margot. Os Macondes de Moçambique: Cultura Material. Lisboa: Junta de Investigações do Ultramar, 1964. $2 \mathrm{v}$.

DIAS, Margot. O fenómeno da escultura maconde chamada "moderna". Lisboa: Junta de Investigações do Ultramar, 1973.

FERREIRINHA, Felisberto. A estatuária dos macondes. In: Separata da Sociedade de Estudos da Colónia de Moçambique. Lourenço Marques: [s.n.], 1949.

GROHS, Elisabeth. Moderne Makonde-Plastik. Stuttgart: Baessler-Archiv, 1971, n. 19, p. 263-297.

KANGAI, Phibion; MUPONDI, Joseph George. Africa digests the west: A review of modernism and the influence of patrons-cum brokers on the style and form of southern eastern and central African art. Academic Research International, Lodhran (Pakistan): SAVAP International (Society for the Advancement of Education through Visionary Academicians/Researchers for Peaceful Globe), v. 4, n. 1, p. 193-200, jan. 2013.

KANT, Immanuel. Crítica da Faculdade de Julgar. São Paulo: Ícone Editora, 2009.

KASFIR, Sidney. African Art and Authenticity: A Text with a Shadow. African Arts, Los Angeles: UCLA James S. Coleman African Studies Center, v. 5, n. 2, p. 40-53, abr. 1992.

KINGDON, Zachary. A host of devils: The history and context of the making of Makonde spirit sculpture. London: Routledge, 2002. (Studies in visual culture, 2).

LARANJEIRA, Lia Dias. Mashinamu na Uhuru: conexões entre a produção de arte makonde e a história política de Moçambique (1950-1974). São Paulo, 2016. Tese (Doutorado) Faculdade de Filosofia, Letras e Ciências Humanas, Universidade de São Paulo.

LEITE, Pedro Pereira. A emergência da escultura maconde como símbolo da moçambicanidade. Lusotopias - Revista de Geocultura, Coimbra, n. 2, 2015. Disponível em: <https://www. researchgate.net/publication/290448619_Lusotopias_-_Revista_de_Geocultura>. Acesso em: 28 dez. 2015.

LIESEGANG, Gergard. Sur les origines et l'histoire des Makondé du Mazambique. In: Dominique Macondé: Mozambique, La Réunion. Réunion: Musée Historique de Villèle, 2007. Catálogo de exposição.

LIMA, Luiz Costa. A autonomia da arte e o mercado. ARS, São Paulo, v. 2, n. 3, p. 102-116, 2004. Disponível em: <http://www.scielo.br/scielo.php?script=sci_arttext\&pid=S167853202004000300009\&lng=en\&nrm=iso>. Acesso em: 27 jan. 2016.

PÉLISSIER, René. História de Moçambique: formação e oposição (1854-1918). Lisboa: Editorial Estampa, 1994. $1 \mathrm{v}$. 
PRICE, Sally. A arte primitiva em centros civilizados. Rio de Janeiro: UFRJ Editora, 2000.

RICH, Vicent. Carving a Life: The Political Economy of Woodcarver Livelihoods in Cabo Delgado, Northern Mozambique. London, 2012. Tese (Doutorado) - Department of Development Studies School of Oriental and African Studies, University of London.

RITA-FERREIRA, António. Fixação portuguesa e história pré-colonial de Moçambique. Lisboa: Instituto de Investigação Científica Tropical, Junta de Investigações Científicas do Ultramar, 1982.

SHULE, Vicensia. Mwalimu Nyerere: the artist. In: CHACHAGE, Chambi; CASSAM, Annar (orgs.). Africa's libertation: the legacy of Nyerere. Cape Town, Dakar, Nairobi, Oxford: Pambazuka Press; Kampala: Fountain Publishers, 2010, p. 160-174.

STOUT, John Anthony. Modern Makonde Sculpture. Nairobi: Kibo Art Gallery Publications, 1966.

THOMAZ, Omar Ribeiro. Ecos do Atlântico Sul: representações sobre o terceiro império português. Rio de Janeiro: Editora UFRJ, 2002.

WEULE, Karl. Resultados científicos de minha viagem de pesquisas etnográficas no sudeste da África Oriental. Maputo: Ministério da Cultura; Departamento de Museus, 2000.

\section{ENTREVISTAS}

Matias Ntundo, aldeia de Namdimba (Planalto de Mueda), 10 de novembro de 2013.

Geraldo Pitamwiu, Pemba, 15 de novembro de 2013. 